\title{
Candidate Tumor Suppressor Gene
}

National Cancer Institute

\section{Source}

National Cancer Institute. Candidate Tumor Suppressor Gene. NCI Thesaurus. Code C49238.

A gene whose loss or inactivation is associated with one or more types of cancer.

However, the function of the gene is currently unknown or has not been characterized. 